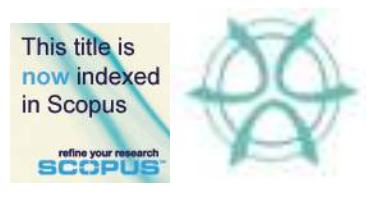

PLANNING MALAYSIA:

Journal of the Malaysian Institute of Planners

SPECIAL ISSUE IV (2016), Page 329 - 342

\title{
THE EVOLVEMENT OF BRAND IDENTITY OF LANGKAWI ISLAND, MALAYSIA
}

\author{
Mohd Fadil Mohd Yusof ${ }^{1} \&$ Hairul Nizam Ismail ${ }^{2}$ \\ ${ }^{1,2}$ Faculty of Built Environment \\ UNIVERSITI TEKNOLOGI MALAYSIA
}

\begin{abstract}
The purpose of this paper is to investigate the brand identity development efforts of Langkawi Island as one of the most prominent and well-guarded tourism destinations in Malaysia. It will be viewed from the historical perspectives for the last 35 years since the 1980s until the present time as to how this involvement influences the formation of its brand identity and later, the existing destination image. Based on in-depth interviews with eleven different levels of managers of separate divisions for destination management organizations (DMOs) in Langkawi Island, Malaysia, theoretically, the findings provide an opportunity to expand the knowledge of destination brand identity development and the involvement of DMOs in influencing image making over time. Practically, the findings indicate three key important antecedents of brand identity development efforts related to: (1) the effects from multiple positioning themes and slogans, (2) the important of brand coordination, and (3) brand leadership issue. These empirical findings provide new insights into enhancing the theoretical aspect of managing a destination brand, including its close relationship with issues faced by destination marketing organizations in managing destination branding strategy. Thus, using the case study of Langkawi Island, the context of multiple identities or image fragmentation is important to be understood due to the different perceived ideas on how the image should be projected according to stakeholders and market segmentation.
\end{abstract}

Keyword: Brand identity development, Langkawi, Malaysia, stakeholders, branding slogans, DMOs

\section{INTRODUCTION}

Destination brand identity is one of the important core concepts that have been discussed in destination branding literature (e.g. Bregoli 2012; Mak 2011; Saraniemi 2011; Wheeler, Frost, \& Weiler 2011). Mak (2011) has explored destination brand identity from the DMO's industry partners, while Saraniemi (2011) investigates the destination brand building activities by the National Tourism Organization (NTO), drawing from the identity based branding literature. Wheeler et al. (2011) have indicated that a destination brand developed could be incongruent with the destination product offerings and their identity. They also point out that internal stakeholders such as tourism operators and local communities may perceive a destination brand that does not conform to the values and its 
Mohd Fadil Mohd Yusof \& Hairul Nizam Ismail

The Evolvement of Brand Identity of Langkawi Island, Malaysia

identity if the brand is enforced by the authority. In short, brand identity development is important as it represents the brand from a supply perspective.

Most of the destination branding studies discussed and examined the brand from the demand perspective or visitors to the destination (García, Gómez, \& Molina 2012; Konecnik \& Go 2008). From the branding literature, examining the brand from the demand side is defined as a brand image and from the supply side is as a brand identity. Both perspectives should be taken into account to get a holistic view of the success of destination branding strategy (Bregoli 2012; Saraniemi 2010). From a general marketing point of view, brand identity and brand image are related, but they are two different concepts (Lin, Pearson, \& Cai 2010). In short, the key difference between these two concepts is that identity comes from the company whereas the image is an individual's perception of a particular brand (Nandan, 2005).

Although destination branding has been one of the topics that has gained attention in destination management research, the development process of destination identity or brand identity has yet to be adequately addressed, particularly in a tourism destination of a developing country. More studies are observed in the context of destination identity and its sense of place in relation to destination brand identity development (e.g. Campelo, Aitken, Thyne, \& Gnoth 2013; Konecnik \& Go 2008; Konecnik Ruzzier \& de Chernatony 2013; Wheeler, Frost, \& Weiler 2011). However, fewer studies are reported in terms of tracking the evolvement of destination brand identity over a period of time due to the development of the tourism industry of a particular area. This paper examines the brand identity development efforts from a historical perspective of the way a destination is positioned using multiple branding slogans or positioning themes to be promoted as a competitive tourism destination. Using Langkawi Island, one of the most prominent and well-guarded tourism destinations in Malaysia as a study context, multiple documents such as official reports and archival materials were analyzed to examine how brand identity is changed to attract multiple market segmentations for a period of over three decades. This study also performed in-depth interviews with various key officers of a destination development authority, a National Tourism Organization and with a destination local municipal council to get their perspective on the brand identity development efforts that seem to have changed due to more tourism products being introduced to cater to multiple market segmentations.

The significant involvements of various policymakers such as destination management organizations, (DMOs), local city councils and national tourism organizations (NTOs) in destination's tourism success, particularly in branding strategy, are vastly discussed in the destination branding literature (e.g. Bornhorst, Ritchie, \& Sheehan 2010; Pike 2007; Volgger \& Pechlaner 2014). To remain competitive in the tourism marketplace, many destinations have established a DMO to provide leadership in managing tourist destination (Bornhorst, Ritchie, \& Sheehan 2010; Steven Pike \& Page 2014). One of the important roles performed by DMOs is to brand a destination as unique and attractive to attract more visitors to the area. Therefore, DMOs have increased the amount of investment for branding activities and the efforts are observed since the 1990s (Pike 2007). DMOs are recognized as the principal of branding strategists for a destination. In branding a destination, DMOs are in charge of crafting the overall brand strategy. In the literature, the term DMO refers either to destination marketing organization or destination management organization and is used interchangeably to 
highlight the multiple responsibilities of such organizations. Normally, lead DMOs can be nations, states, local governments or specific tourism entities such as a Convention and Visitors Bureau (Zavattaro, Daspit, \& Adams 2015).

However, in Malaysia, the term DMO mainly refers to either National Tourism Organization (NTO) or a development authority where specifically in the case of Langkawi Island, it is a destination development authority and National Tourism Organization (Tourism Malaysia). Both organizations are funded by the federal government. Local government authorities also have their role in supporting the tourism industry, but they are not directly involved in destination branding strategy. In the case of Langkawi, in order to develop the island as a prime international tourism destination, the government has established Langkawi Development Authority in the year 1990. The primary role of the agency is to plan, stimulate and coordinate of the overall development of the island where the locals may reap the maximum benefits from all the tourism activities and development (Samat 2010). The agency is also responsible in positioning the island as one of the top tourism destinations globally through its various tourism product offerings and identifying market segmentations.

Brands as described in the literature are supposed to be a clear and distinct image which differentiates them from the competitors (Baker \& Cameron 2008). Similarly, in destination image literature, branding efforts should be framed within a clear image strategy (Gartner 1993). Pike (2010) also mentions that a destination should have a clear identity to remain competitive. However, as argued by Ren \& Blichfeldt (2011), the literature does not provide much explanation towards the meaning of 'clear identity or a clear image strategy'. Therefore, lack of clear identity or having multiple identities or images as perceived by both from internal stakeholder's perspective or the visitors do not necessarily mean something negative. These different views are to be expected and acknowledged. As long as the destination can deliver what it promises, it is acceptable to have multiple projected images.

\section{Slogans and positioning themes as part of identity development}

Having a slogan is part of the branding efforts to promote a destination. Most destinations use a branding slogan as part of their brand positioning strategy (Pike, 2005). In order to associate between the brand identity desired by DMOs and the actual brand image held in the market, destinations provide various slogans as one to differentiate from others. A slogan is defined as a short phrase that is easy to remember and is used to convey the values of a destination to the visitors for them to experience (Rehan 2014). Slogan is supposed to be attractive, commercialized and catchy to be associated with a brand. A destination is identified through a slogan and very often a powerful image is projected by developing a slogan that visitors can easily remember such as 'I love NY', 'Malaysia Truly Asia' and 'Amazing Thailand'. The main purpose of a slogan is to communicate key descriptive features of a place such as a tourism destination or a country (Supphellen 2002). From the general branding perspective, slogans are part of the identity elements and used to differentiate a brand (Keller 2013). Slogans are powerful branding tools because, like brand names, they are an extremely efficient, shorthand means to build brand equity (Keller 2013: 158). Similarly, in branding a destination, slogan is used to create brand awareness and to reinforce the brand positioning. However, developing an effective slogan or tagline for a destination is much more complicated than for consumer 
Mohd Fadil Mohd Yusof \& Hairul Nizam Ismail

The Evolvement of Brand Identity of Langkawi Island, Malaysia

and corporate brands (Supphellen, 2002). As claimed by Pike (2012), DMOs experience several challenges in developing meaningful positioning themes that represent the needs of diverse markets as well as the range and diversity of local attractions and product offerings.

\section{Brand coordination}

Branding a destination is mostly coordinated by destination management organizations, which are normally administered and funded by a government authority. It is recognized in the literature that coordination among different stakeholders is one of the important factors determining the success of a destination brand (Bregoli 2012). However, internal coordination between departments, divisions or unit within DMO is also critical in building and implementing a successful branding strategy (Hankinson 2007). Hankinson argued that developing brand identity begins with the DMO from the top management of the organization to the entire staff members. Subsequently, the brand identity is extended and coordinated with other partner organizations.

\section{Brand leadership issues}

Brand leadership is one of the important guiding principles for destination brands. Based on the corporate branding theories, Hankinson (2007) argues that a strong, visionary leadership is critical to brand a destination efficiently. Managing and developing brand identity is a process performed by the DMO whereby the organization as whole decides a vision and strategy for the brand creation (Kavaratzis, 2009). As suggested by Kavaratzis (2009), the DMO has to inculcate the brand culture of the organization, focusing on the internal brand identity development among its entire staff members first. The next step is to promote the brand with other organizations in order to build alliances and partnerships as part of the external brand identity development. The last step is to communicate the brand promise and to deliver the brand experience with the multiple stakeholders that are involved in the branding process.

\section{METHODOLOGY}

In order to investigate the brand identity development efforts of Langkawi Island and its image projected over a period of 35 years (1980-2015), it was decided to conduct field interviews with a sample of senior key persons from different organizations operating on the island. The data were gathered by interviewing seven different division managers of the destination planning and development authority including the CEO, three different level managers of the National Tourism Organization and the president of the local municipal council. All participants were selected based on their experience, knowledge and their roles in influencing the brand identity developments of Langkawi Island from DMO's perspective. A total of twelve participants were contacted to participate in the study. Official letters were sent through emails to senior managers in charge of tourism, asking the person and other related officers to participate in the study. A separate letter was sent to the CEO of the development authority through his personal assistant also by email for the same purpose. A follow up phone call was made a week after the email was sent to reconfirm the interviews which would take place in Langkawi. Details of the participants representing respective organizations with different levels of managerial positions and roles are presented in Table 1. 
As mentioned by Saraniemi (2010), the data collected from interviews with the selected respondents may not represent the actual realities of the events or phenomenon as in every historical research. Therefore, this study made efforts to cross-check and verify several times against secondary data of multiple archive reports published by the relevant authorities such as Visitor Destination Plan and other development plans and reports during the years (Saraniemi, 2010).

Table 1: Details of individuals interviewed representing different levels of management and divisions

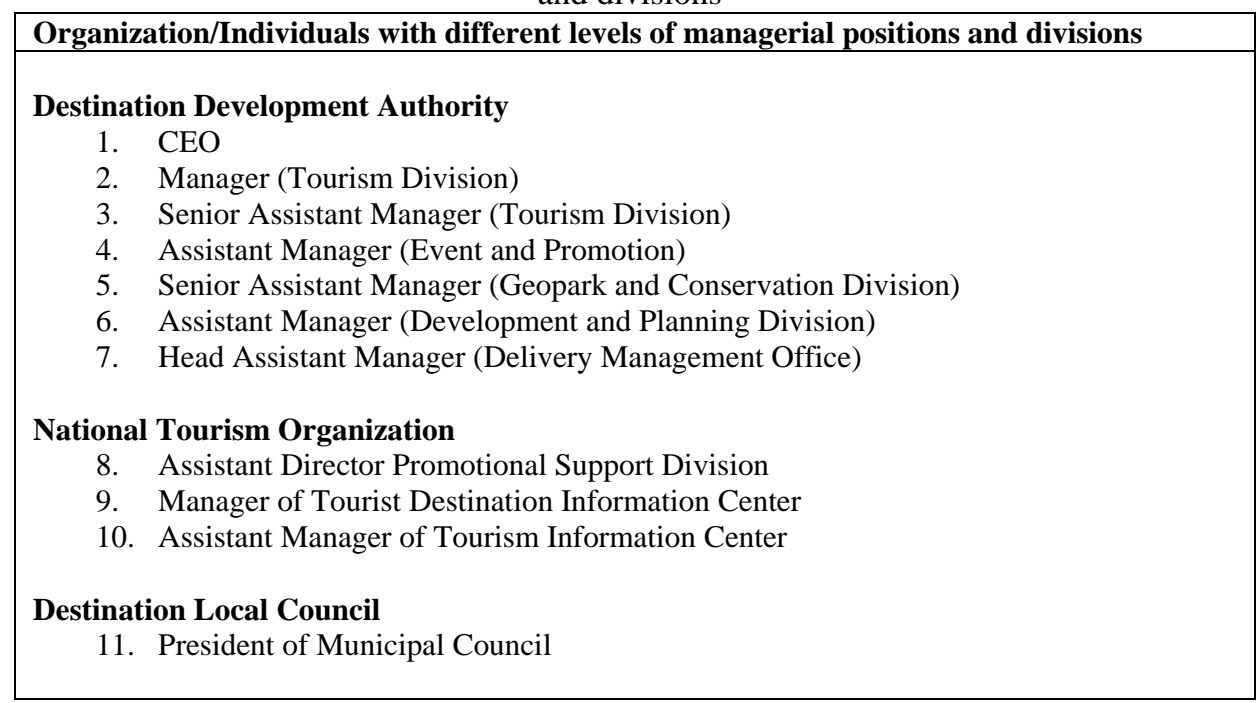

To explain how the destination identity developments evolved over the period of 35 years (1980-2015), a series of questions were addressed regarding the multiple taglines or themes used to project the image of the destination during that period of time, including how managers: 1) perceive the changes of different slogans, 2) identify the core values or actual identity of the destination, 3) engage with other internal stakeholders such as tourism operators and local community, and 4) react to change of leadership. The examples of the questions used were as follows: "Can you tell me about Langkawi's identity and its core values?"; "How would you engage with other important stakeholders in creating the brand identity?"; "Why were there different slogans or taglines used to represent Langkawi over the period of 35 years?" These questions were asked to most of the respondents to obtain their views on the evolvement of the destination identity.

The researcher used semi-structured questionnaire to guide the interviews. Nine interviews were tape recorded. Two of the respondents refused the interview to be recorded where the researcher had to resort to writing notes during the session. The interviews were conducted separately over the period of seven months starting from October 2014 until April 2015 due to different schedules of the managers and their time constraints. It was challenging to interview some of the managers and the CEO as they were always on official trips and attending multiple events and functions. The interviews took times varying from about 15 to 60 minutes and they were transcribed immediately 
Mohd Fadil Mohd Yusof \& Hairul Nizam Ismail

The Evolvement of Brand Identity of Langkawi Island, Malaysia

after each interview to have a clear understanding of the studied case (Okumus, Altinay, $\&$ Roper 2007). The researcher read all the transcribed documents several times and examined the patterns that emerged. All the transcriptions were coded accordingly. The researcher focused on the patterns identified that relate to the evolvement of destination identity development efforts from different periods based on the views from managers of the destination development authority, the national tourism organization and the president of the municipal council. To provide a comprehensive picture of destination brand development efforts of Langkawi over the last 35 years, besides in-depth interviews data, the researcher also referred to other sources of information including websites and destination official portal, promotional materials, official annual reports and other related documents.

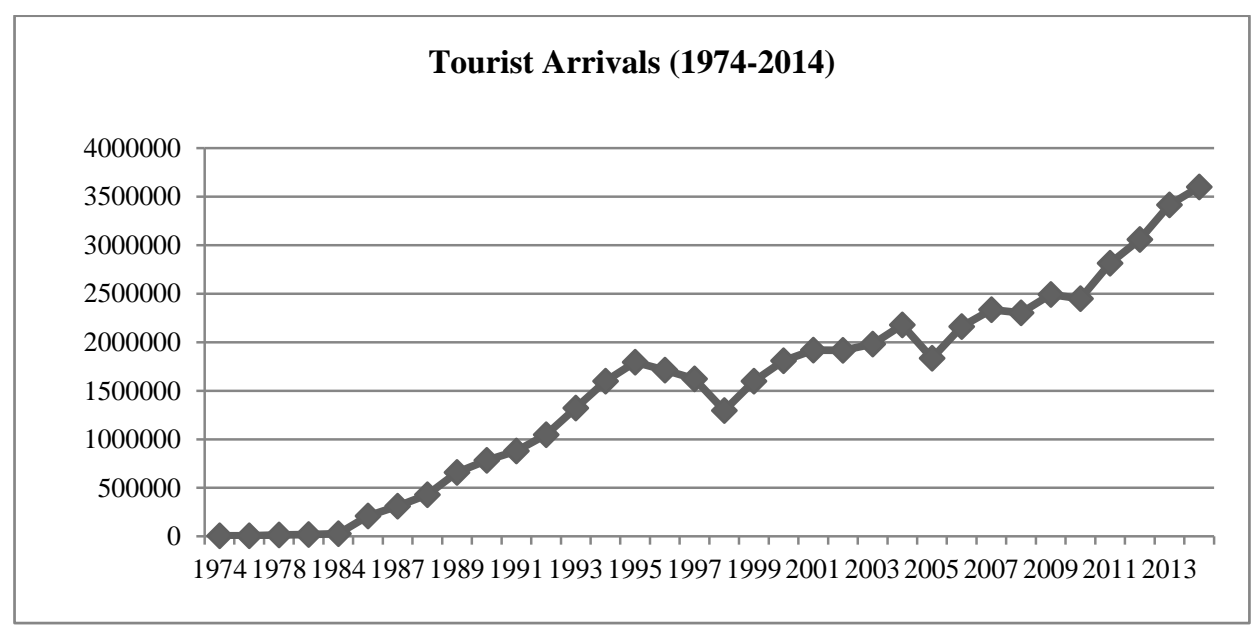

Figure 1: Increasing Tourist Arrivals to Langkawi Island (1974-2014)

Source: Langkawi Development Authority (LADA) (2013) and Langkawi Development Authority (LADA) (2015, online $)$

\section{RESULTS AND DISCUSSIONS}

\section{Multiple taglines and positioning themes}

It was discovered that between 1980 and 2015, Langkawi Island had many positioning themes or taglines introduced to market the island as a tourism destination. All participants agreed that over a period of 35 years from 1980-2015, Langkawi has reinforced multiple images through different themes or slogans including the 'Isles of Legends', 'Duty Free Islands', '99 Magical Islands', 'Tourism City', 'The Jewel of Kedah', 'Langkawi Global Geopark' and 'Naturally Langkawi'. For example, according to a CEO of Langkawi Development Authority:

..There are many taglines... when we talk about branding and marketing, there must be a tagline, and the same observation was made by the consultant appointed by the government. 
I mean 99 islands, and then 99 Magical islands, the Jewel of Kedah, the Jewel of Kedah is not the commercial branding, Langkawi the Isle of Legends. So we need the commercial branding.

However, not all of the taglines or slogans really represent the official branding slogans of the island. Some of the taglines were simply used to introduce and position the island on the global tourism map. As explained by a manager of tourism division, the official branding of the island started following the release of the Langkawi Tourism Blueprint in 2011 by the Prime Minister Najib Razak. In year 2012, the island embarked on the official branding campaign under the theme 'Naturally Langkawi'. She emphasized on the importance of the blueprint to Langkawi's tourism industry:

The blueprint is the plan that was prepared by the EPU(Economic Planning Unit) exclusively to revive the tourism industry unlike other previous Langkawi plans which stressed more on planning and developing the island.

All the labels used seem to work in attracting different markets to the island. Tourist arrivals have grown substantially over that period of time as shown in Figure 1. Figure 1 illustrates the upwards trend of tourists arrivals starting from 1974 until 2014. As depicted in Figure 1, the total number of tourist arrivals depends on the global economic conditions and external global environment as the figures fluctuate due to events such as Asian financial and economic crisis (1996-1998), terrorism (Bali bombings in 2002) and natural disaster (tsunami event in 2004). In 2013, Langkawi recorded total tourist receipt of approximately MYR $\$ 4.5$ billion from the arrival of 3.4 million tourists representing domestic and international visitors (LADA, 2013). In the same year, Malaysia's tourist receipt was recorded at MYR $\$ 65.44$ billion and Langkawi's tourist receipt alone represented 7\% of the total tourist receipts of the whole country. Therefore, the tourism industry now is the biggest industry on the island and the local people appear to enjoy the economic benefits gained from the industry. Majority of the local people are engaged in the tourism industry, working in the hotels, operating resorts and chalets as well as managing or guiding tours.

In analyzing the Langkawi destination identity, it is found that Langkawi holds different identities to different market segmentations. According to one of the senior managers of tourism division for Langkawi development authority, Langkawi is perceived with different identities and images by different markets:

Event organizers want to have events here. The local people want to come here for shopping, the foreign tourists come here to enjoy the natural beauty, natural landscapes, beaches and soft adventures activities such as walking in the jungle trail, birding and so on.

The same sentiment was echoed by a manager of tourist information centre when making some observation on the island's multiple market segmentations:

Domestic market is important for the island. Most of them come to the island for shopping activities because of the island's duty free status. The duty free status is 
Mohd Fadil Mohd Yusof \& Hairul Nizam Ismail

The Evolvement of Brand Identity of Langkawi Island, Malaysia

appealing to the market. Most hotels around Kuah town survive because of the domestic market.

The various taglines introduced by the authority appear to relate to different target markets that keep on changing over time. In the 80s, for example, the tagline used was 'Langkawi, the Isle of Legends' and in the 90s, the tagline changed to 'Langkawi - 99 Magical Islands in the Sun'. In the mid-20s, the tagline changed again to Langkawi Global Geopark and in year 2013, the authority released its official branding strategy of the island under the official tagline of 'Naturally Langkawi'. When asked why the taglines are changing, a senior manager who has been on the island for over ten years and working with the development authority responded:

There are different tourist market segments going to Langkawi. There are many markets from different countries. For example, European tourists, they love nature and therefore we focus on nature, rainforests and mangroves. But if the tourists are from China, they don't go for nature, they like beaches. So we have to focus on beaches. That is why we use 99 Islands in the sun; the element of sun is there. The Jewel of Kedah is for the local domestic tourists, those local mass tourists. The duty free Island actually attracts the local domestic tourists...

These comments narrate to the destination brand identity development efforts where image projected by the authority varies based on different target markets. For the last 35 years from 1980-2015, Langkawi Island has been positioned with different themes and slogans to reflect the changing markets over time. However, some of the taglines did not came directly from the agency office but from the previous elected state government, which was consented by the Royal Sultan of Kedah (Langkawi the Jewel of Kedah), and the Ministry of Local Government (Langkawi Tourism City). When asked about how and why Langkawi used different branding slogans over that period of time, one of the managers mentioned:

Langkawi Tourism City is a status awarded by Ministry of Local Government to elevate the status of Langkawi as a modern tourism city especially for the domestic market. Once you get city status, there will be more funds directed from the government to further develop Langkawi....Langkawi the Jewel of Kedah was proposed by the previous elected Kedah opposition party and it was consented by the Sultan of Kedah to show that Langkawi is still part of Kedah and long before that it is 99 Magical Islands.

The empirical evidence of this study indicates that destination identity development is influenced by different stakeholders' involvements, which are politically related. Granting Langkawi as a tourism city and being recognized by the Ministry of Local government as a tourism city had provided access for the destination to get more funding to develop the island's tourism. As a result, more funds are channelled to the developing authority in improving local infrastructures such as road conditions and enhancing other tourism infrastructures and therefore modernizing the island to cater to international tourists. The slogan 'Langkawi the Jewel of Kedah' was mooted by the 
previous elected state government to indicate that Langkawi is still part of Kedah and not completely owned by the federal government. Therefore, the purpose of branding is not only to attract more visitors to the island but also to get more funding from the government and potential investors to further develop the island. At the same time, the branding slogan such as Langkawi, The Jewel of Kedah is supposed to create a sense of belonging and sense of ownership among the local residents towards the Langkawi brand.

Brand coordination is one of the critical issues that are raised by the development authority managers and those officers from Tourism Information Centre. In the case of Langkawi, there is empirical evidence observed in terms of brand coordination within different divisions among a particular development authority as well as coordination with the other tourism organizations. There are some efforts by the authority to create brand awareness among the local community and tourism operators. However, local people's attitude towards various projected identities by the authority appears to be indifferent towards the branding strategy. According to a manager of one of the divisions, the locals are not significantly involved in the efforts performed by the authority in regards to the branding efforts of the island:

There is little involvement from the local people in our branding strategy. But the only thing that they want is they enjoy development, if they look back at themselves where they were before and where they are now, I think they are happy.

A CEO of the Authority concurred with the observation made by his manager in regards to little involvement from the local people, where he feels that local people need time to adapt with the island's current branding strategy due to their lack of knowledge and concerns towards the brand:

I know it takes time, because, well, we have to face it, do you think they (local people) know about marketing? About branding? They have little knowledge in or even know nothing about marketing and branding. To them, as long as more tourists are coming, it is alright.

However, the CEO agreed that community acceptance towards the official brand is important and the authority is making efforts so that the brand will be accepted by the local people over time when he stated:

We try our level best so that this brand will be accepted, there are some people who are very sentimental with this, so, it will take a while, before they will accept this new brand.

Some of managers from different divisions of the DMO have little understanding what the brand is and why the brand is important. As a result, this little coordination contributes to lack of understanding and confusion among managers towards the brand promise. For example, one of the managers associated with the Geopark mentioned that she has little understanding towards the authority's branding strategy: 
Mohd Fadil Mohd Yusof \& Hairul Nizam Ismail

The Evolvement of Brand Identity of Langkawi Island, Malaysia

I don't know how to comment about Langkawi's branding. Well, Langkawi Geopark is not really a brand, it is just a concept. However, it becomes a brand because Langkawi Global Geopark is recognized by the UNESCO. Geopark becomes marketable because of its recognition from the world body. That is what I have been told. I have no idea what a brand is, really. I am sorry.

On the contrary, the other manager from a different division mentioned that Langkawi Geopark is really a sellable brand:

Currently, we are using Langkawi Global Geopark as a brand and Tourism Malaysia also uses it because it is a sellable brand, UNESCO Global Geopark. UNESCO is an international brand, so we definitely have the international platform to be seen in the tourism industry. We need to be seen and be present in this industry.

Based on this data, apparently, each division among the same organization has different levels of understanding towards interpreting the brand where in this case is the Langkawi Global Geopark brand. Some divisions may have in-depth knowledge about the projected brand identity and its values while the others may not.

According to one of the managers in charge of planning and development division, there are on-going efforts from the authority to collaborate with the other agencies in revising the local plan to align with the current authority's projected identity of the island as an eco-tourism destination. For example, the agency and Langkawi local authority (MPL) are currently reviewing the local plan and proposing solutions to develop the island in a sustainable way.

Leadership skills among the appointed CEO or General Manager of the development authority play important roles in influencing the destination brand identity efforts over the last 35 years of tourism development on the island. Since the agency was established in 1990, there have been six changes to its general managerial position, with a new CEO, a retired senior government officer appointed in year 2012 until the present time. All the General Managers or CEO of the agency were appointed by the government among government senior officers who previously were attached to different government agencies and ministry such as from administrative and diplomatic offices, finance, district, mineral and land offices. Each CEO has different leadership styles and their enthusiasm towards developing Langkawi as a destination brands varies. Every time a new GM is appointed, there will be changes in the way the agency is managed. Some CEOs were enthusiastic in developing Langkawi and came up with different ideas to advance the tourism industry while some were too focused on bureaucratic procedures to the extent that it limits the island's overall tourism development.

\section{CONCLUSION}

In the case of Langkawi Island, the role of DMO in the form of development authority is of utmost importance. The government's traditional top-down approach through its various agencies such as its Development Authority and National Tourism Organization (NTO) has influenced much of the brand identity development efforts of Langkawi over the last 35 years from 1980 until 2015. Since most of the tourism development could only 
be done by the government, Langkawi through its Development Authority has been positioned with different themes and slogans to attract different market segmentations but with little consultation from its wider stakeholders (e.g. tourism operators, local community, etc). However, given the increasing number of tourist arrival over that period of time, the strategy of multiple projected images seems to be working well with Langkawi.

For the last 35 years, the development authority is in charge of implementing various tourism projects as well as constructing tourism facilities and attractions that cater to both local and foreign tourists the island. This traditional approach practiced by DMO in emphasizing brand identity development efforts on projected multiple images towards visitors alone could be less efficient in enhancing the destination brand values (García, Gómez, \& Molina 2012). It could be successful in attracting more tourists but eventually, the DMO may end up losing support from the other important stakeholders such as business operators and local community. In the case of Langkawi, it is time for the DMO to rethink its branding strategy by engaging more dialogues with the stakeholders and find ways to connect with the local people effectively. At the same time, considering that the authority is pursuing destination branding strategy to differentiate the island from the others aggressively, it is important that they first really understand the brand values. Branding strategy is a complicated process because it is involved with different stakeholders with diverse interests. Given the important roles of widest stakeholders in supporting any brand promoted by the DMO, striking an acceptable balance between the demand and supply approach in branding strategy is very critical. The process of constructing a strong brand starts with the DMO and is later extended to other related partner organizations (Hankinson 2007). Therefore, it is critical that all employees from all divisions of DMO to clearly understand the projected identities and the brand values that the organization attempts to convey.

Therefore, more concerted branding efforts are needed to position a destination to be competitive. It is suggested for DMO to intensify their efforts in engaging with the wider stakeholders to make a brand a success. Supports from different stakeholders are important to deliver the brand promise. Having slogans or interesting labels are important for branding but what is most important is whether a destination can deliver the promises or values or not. A bottom-up approach that promotes engagement with a range of different stakeholders may provide strengths to the brand identity development, which include public and private partnership (Woodland \& Acott 2007). At the same time, DMO has to inculcate a brand culture among its employees across different divisions by educating them through workshops and training related to destination brand (Hankinson 2007). 
Mohd Fadil Mohd Yusof \& Hairul Nizam Ismail

The Evolvement of Brand Identity of Langkawi Island, Malaysia

\section{ACKNOWLEDGEMENT}

This paper is part of the currently undergoing doctorate research on Destination Brand Identity Development Efforts conducted by a doctorate student, Mohd Fadil Mohd Yusof with the supervision from Associate Professor Dr. Hairul Nizam Ismail. This study is very much indebted to Universiti Malaysia Kelantan (UMK) and Ministry of Higher Education through a research grant R/RAGS/A01.00/00418A/002/2013/000131. The paper was presented at the $13^{\text {th }}$ International Congress of Asian Planning Schools AssociationAPSA 2015, at Universiti Teknologi Malaysia, Johor, Malaysia, on 12-14August, 2015. The authors also would like to thank Langkawi Development Authority (LADA) for providing information and relevant data for the research.

\section{REFERENCES}

Baker, M. J., \& Cameron, E. (2008). Critical success factors in destination marketing. Tourism and Hospitality Research, 8(2), 79-97. doi:10.1057/thr.2008.9

Bornhorst, T., Ritchie, J. R. B., \& Sheehan, L. (2010). Determinants of tourism success for DMOs \& destinations: An empirical examination of stakeholders ' $\begin{array}{lll}\text { perspectives. } & \text { Tourism } \quad \text { Management, } & \text { 31(5), }\end{array}$ doi:10.1016/j.tourman.2009.06.008

Bregoli, I. (2012). Effects of DMO Coordination on Destination Brand Identity: A MixedMethod Study on the City of Edinburgh. Journal of Travel Research, 52(2), 212224. doi:10.1177/0047287512461566

Campelo, A., Aitken, R., Thyne, M., \& Gnoth, J. (2013). Sense of Place: The Importance for Destination Branding. Journal of Travel Research, 53(2), 154-166. doi:10.1177/0047287513496474

García, J. A., Gómez, M., \& Molina, A. (2012). A destination-branding model: An empirical analysis based on stakeholders. Tourism Management, 33, 646-661. doi:10.1016/j.tourman.2011.07.006

Gartner, W. C. (1993). Image Formation Process. Journal of Travel \& Tourism Marketing, 2, 191-216. doi:10.1300/J073v02n02_12

Hankinson, G. (2007). The management of destination brands: Five guiding principles based on recent developments in corporate branding theory. Journal of Brand Management, 14(3), 240-254. doi:10.1057/palgrave.bm.2550065

Kavaratzis, M. (2009). Cities and their brands: Lessons from corporate branding. Place Branding and Public Diplomacy, 5(1), 26-37. doi:10.1057/pb.2008.3

Keller, K. L. (2013). Brand identity and positioning. Strategic Brand Management, 149177.

Konecnik, M., \& Go, F. (2008). Tourism destination brand identity: The case of Slovenia. Journal of Brand Management, 15(3), 177-189. doi:10.1057/palgrave.bm.2550114

Konecnik Ruzzier, M., \& de Chernatony, L. (2013). Developing and applying a place brand identity model: The case of Slovenia. Journal of Business Research, 66(1), 45-52. doi:10.1016/j.jbusres.2012.05.023

LADA. (2013). Langkawi Development Authority (LADA) Annual Report 2013.

LADA. (2015). "Tourist statistics." Retrieved October 12, 2015, from http://www.lada.gov.my/v2/en/information/tourist-statistic.html 
Lin, Y.-C., Pearson, T. E., \& Cai, L. a. (2010). Food as a form of destination identity: A tourism destination brand perspective. Tourism and Hospitality Research, 11(1), 30-48. doi:10.1057/thr.2010.22

Mak, A. K. Y. (2011). An identity-centered approach to place branding: Case of industry partners' evaluation of Iowa's destination image. Journal of Brand Management. doi: $10.1057 / \mathrm{bm} .2010 .56$

Nandan, S. (2005). An exploration of the brand identity-brand image linkage: A communications perspective. Journal of Brand Management, 12(4), 264-278. doi:10.1057/palgrave.bm.2540222

Okumus, F., Altinay, L., \& Roper, A. (2007). Gaining access for research. Annals of Tourism Research, 34(1), 7-26. doi:10.1016/j.annals.2006.07.006

Pike, S. (2005). Tourism destination branding complexity. Journal of Product \& Brand Management, 14(4), 258-259. doi:10.1108/10610420510609267

Pike, S. (2007). Consumer-Based Brand Equity for Destinations Consumer-Based Brand Equity for Destinations : Practical DMO Performance Measures. Journal of Travel and Tourism Marketing, 1(22), 37-41. doi:10.1300/J073v22n01

Pike, S. (2010). Destination Branding Case Study: Tracking Brand Equity for an Emerging Destination Between 2003 and 2007. Journal of Hospitality \& Tourism Research. doi:10.1177/1096348009349820

Pike, S. (2012). Destination positioning opportunities using personal values: Elicited through the Repertory Test with Laddering Analysis. Tourism Management, 33(1), 100-107. doi:10.1016/j.tourman.2011.02.008

Pike, S., \& Page, S. J. (2014). Destination Marketing Organizations and destination marketing: A narrative analysis of the literature. Tourism Management, 41, 202 227. doi:10.1016/j.tourman.2013.09.009

Rehan, R. M. (2014). Urban branding as an effective sustainability tool in urban development. HBRC Journal, 10(2), 222-230. doi:10.1016/j.hbrcj.2013.11.007

Ren, C., \& Blichfeldt, B. S. (2011). One Clear Image? Challenging Simplicity in Place Branding. Scandinavian Journal of Hospitality and Tourism, 11, 416-434. doi:10.1080/15022250.2011.598753

Samat, N. (2010). Assessing Land Use Land Cover Changes in Langkawi Island: Towards Sustainable Urban Living. Malaysian Journal of Environmental Management, 11(1), 48-57.

Saraniemi, S. (2010). Destination brand identity development and value system. Tourism Review, 65(2), 52-60. doi:10.1108/16605371011061624

Saraniemi, S. (2011). From destination image building to identity-based branding. International Journal of Culture, Tourism and Hospitality Research, 5, 247-254 doi:10.1108/17506181111156943

Supphellen, M. (2002). Testing country brand slogans: Conceptual development and empirical illustration of a simple normative model. Journal of Brand Management, 9(4-5), 385-395.

Volgger, M., \& Pechlaner, H. (2014). Requirements for destination management organizations in destination governance: Understanding DMO success. Tourism Management, 41, 64-75. doi:10.1016/j.tourman.2013.09.001 
Mohd Fadil Mohd Yusof \& Hairul Nizam Ismail

The Evolvement of Brand Identity of Langkawi Island, Malaysia

Wheeler, F., Frost, W., \& Weiler, B. (2011). Destination Brand Identity, Values, and Community: A Case Study From Rural Victoria, Australia. Journal of Travel \& Tourism Marketing, 28(1), 13-26. doi:10.1080/10548408.2011.535441

Woodland, M., \& Acott, T. G. (2007). Sustainability and Local Tourism Branding in England's South Downs. Journal of Sustainable Tourism, 15(6), 715-734 doi:10.2167/jost652.0

Zavattaro, S. M., Daspit, J. J., \& Adams, F. G. (2015). Assessing managerial methods for evaluating place brand equity: A qualitative investigation. Tourism Management, 47, 11-21. doi:10.1016/j.tourman.2014.08.018 